\title{
Assessment of risk factors and preventive measures and their relations to work-related musculoskeletal pain among dentists
}

\author{
Nataša Pejčića,*, Vanja Petrovića ${ }^{\mathrm{a}}$, Dejan Markovića ${ }^{\mathrm{a}}$, Biljana Miličićb, Ivana Ilić Dimitrijevićc \\ Neda Perunovićd and Saša Čakićd \\ ${ }^{a}$ Department of Preventive and Pediatric Dentistry, School of Dental Medicine, University of Belgrade, Belgrade, \\ Serbia \\ ${ }^{\mathrm{b}}$ Department of Informatics and Statistics, School of Dental Medicine, University of Belgrade, Belgrade, Serbia \\ ${ }^{\mathrm{c}}$ Department of Maxillofacial Surgery, School of Dental Medicine, University of Belgrade, Belgrade, Serbia \\ ${ }^{\mathrm{d}}$ Department of Periodontology and Oral Medicine, School of Dental Medicine, University of Belgrade, Belgrade, \\ Serbia
}

Received 6 January 2016

Accepted 22 November 2016

\begin{abstract}
.
BACKGROUND: Dentists have a high prevalence of musculoskeletal (MS) pain, which is the most common symptom associated with work-related musculoskeletal disorders (WMSDs). To overcome this problem, identification of the risk factors and preventive measures for MS pain are of paramount importance to dentists in order to improve their quality of life and work.

OBJECTIVES: The aims of this study were to recognize the risk factors for MS pain and their impact on dental work, as well as to identify preventive measures of MS pain among dentists.

METHODS: Self-reporting questionnaire consisting of 78 questions was exclusively developed for the study and sent to 500 working active dentists in Serbia.

RESULTS: Response rate was $71.2 \%$ (356 dentists). The prevalence of MS pain was $82.6 \%$ among dentists. The main risk factors for MS pain were advanced age, female dentists, presence of chronic diseases, long working hours, and high frequency of treated patients. The most effective preventive measures in preventing MS pain were massage treatments and physical activities. Followed by use of ergonomically designed equipment, correct and dynamic working positions, and an adequate workflow organization.

CONCLUSION: The risk factors for MS pain and their impact on dental work should widely be disseminated among dentists. Importantly, proper implementation in everyday life of adequate preventive measures is essential for preventing MS pain and development of WMSDs.
\end{abstract}

Keywords: Risk factors, preventive measures, musculoskeletal disorders, dental work, working performance, working postures

\section{Introduction}

\subsection{Musculoskeletal disorders in dentistry}

*Address for correspondence: Nataša Pejčić, PhD, School of Dentistry, University of Belgrade, Doktora Subotića 211000 Belgrade, Serbia. E-mail: natasadpejcic@yahoo.com.

Dentistry is known as physically highly demanding in comparison with other medical professions [1]. Dentists work in non-ergonomic working 
environments, which include human-tool-human interfaces [2]. Dentists, while performing various dental procedures, have static and awkward postures with repeated motions; consequently, over long periods of time they develop WMSDs [3-6]. According to some authors, WMSDs occur more frequently in dentistry than in other medical professions [5-8].

\subsection{Risk factors for MSDs}

Musculoskeletal disorders (MSDs) are injuries or pain in the body's muscles, bones, nerves, joints, ligaments, and blood vessels. Accumulation of these micro-injuries in the body may develop into a more serious injury over time [9].

Etiology of WMSDs is multi factorial according to the World Health Organization (WHO) [10]. Workplace environment is one of the major factors which can cause and exacerbate WMSDs, but also it is feasible to change most of its aspects. Demographic characteristics, workflow organization, interpersonal relationships at workplace, and health characteristics of dentists are the main fields to look into for the major risk factors for MS pain and development of WMSDs [10, 11].

MS pain is the most common early symptom associated with development and presence of WMSDs [2]. MS pain is very frequent among dentists and the most commonly affected areas include the back, shoulders, and neck [12]. Prolonged static contractions during work are the main physical demands of the dental profession which generates a decrease in oxygenation levels within the muscles and causes accumulation of lactic acid that metabolizes and causes pain $[12,13]$.

Work-related pain experienced by dentists leads to false, slow, and useless movements during work, which causes longer working times, and reduces quality of dental work and satisfaction of patients $[2,14]$.

\subsection{Attempts to combat MS pain}

The well-known concept of four-handed dentistry was born in the $1960 \mathrm{~s}$ and it was one of the main attempts to prevent MSDs in the dental profession. The concept implies adequate positioning between dentist and dental assistant with proper workflow treatment planning and use of adequate ergonomically designed dental equipment [15]. This concept vastly improves the productivity of the dental team and quality of dental procedures. Furthermore it reduces the stress and fatigue felt by a single handed dentist. Although the concept has proposed sitting position and use of ergonomic chairs, seated working position does not reduce MSDs [16]. The prevalence of MS pain among dentists ranges between $64 \%$ and 93\% [5-8]. In addition, some studies indicated that the frequency of MSDs among dentists is even higher in the last decade [13, 17].

Nowadays, use of the optical devices such as loupes and microscopes has increased in the dental profession which are associated with less awkward postures and decreased level of the static muscle load work in different work positions $[18,19]$. Interestingly, there are only a few studies conducted to assess preventive measures for reducing work-related MS pain in dentistry.

\subsection{Contribution of this study in the prevention of MS pain among dentists}

There are many factors which influence dental work (organizational, ergonomically, psychosocially, individuality, etc.) and it is very important to identify which of these factors are related to MS pain. Elimination of these harmful factors and use of effective preventative measures can drastically improve dentists working performance, quality of dental work, and consequently, the satisfaction of patients.

Different countries have conducted studies to determine the prevalence of MS pain within their dental profession [20-22]. In addition, the risk factors for MSDs among dentists is well documented $[2,6-9,20,22]$. So far, the results of various studies have suggested that inappropriate working organizations, use of non-ergonomically designed equipment, and working under pressure are the most common risk factors for MSDs. Importantly, an inadequate dentist's working posture has been recognized as the main risk factor for development of MSDs [1].

On the other hand, the preventive measures of MS pain have not been measured so far and their assessment is of paramount importance for the future dental profession since the increased longevity and increase in retirement age [23].

In order to overcome these problems and make contributions to preventing MS pain and WMSDs in modern dentistry, the main research aims of this study were following: Identifying the risk factors for MS pain during dental work. Evaluating the consequences of the risk factors for MS pain on dental work. Establishing the most effective preventive measures of MS pain among dentists. 


\section{Methods}

\subsection{Study design}

The study used a self-reporting questionnaire (SRQ) which is specially designed by the researchers, as new test instrument. The questionnaire included 78 questions that defined: individual characteristics, socio-economic factors, methods and organization of work, job satisfaction, health status, presence and location of MS pain, applied prophylactic activities and treatment. Most of the questions were close ended. The complete questionnaire is presented in Appendix 1.

The questionnaires from the previous studies focused only on presence and location of MSDs and MS pain but they didn't evaluate the risk factors for MSDs and MS pain and their consequences on dental work. Also they didn't recognize the preventive measures of MSDs and MS pain. Since available questionnaires could not give adequate information to satisfy the research aims of this study, researchers needed to develop a new questionnaire in order to identify the main risk factors for MS pain during dental work and the wide variety of contributing factors for the development of WMSDs. Furthermore, a new questionnaire was needed to assess the consequences of the risk factors for MS pain on dental work and to identify preventive measures of MS pain.

Participants were asked to report pain or discomfort during their work in the last year. The pilot study was performed for validation of the SRQ before its distribution. This questionnaire represents a new method for measuring the effects of risk and protective factors of MS pain.

\subsection{Participants}

Questionnaires were distributed via e-mail to the registered working active dentists from Serbia, whose contacts were in the national base during the year 2015. After two weeks participants were reminded by e-mail. The study included dentists who worked in both the private and public sectors. A total of 500 questionnaires were distributed, with a response rate of $71.2 \%(356 / 500)$.

Exclusion criteria were degenerative, inflammatory rheumatic diseases and diseases of the central nervous system.

Informed consent approved by the Ethics Committee of the Dentistry School, University of Belgrade (number 36/9) was obtained from the participants.
Respondents were able to respond directly, by e-mail, or by post mail. Data was then collected, transferred to the database and statistically analysed.

\subsection{Data analysis}

Statistical analysis was undertaken using SPSS version 18.0 software package, with data analysed using descriptive and analytical methods. Differences in proportions was tested by Pearson's $\chi^{2}$ test and parametric Student's $t$-test or non-parametric MannWhitney test.

Logistic regression analyses were used to determine the risk factors. Results are presented as Odds Ratio (OR), with 95\% CI (95\% confidence interval) and $p$-value. All parameters were analysed in the univariate model, and statistical significances were included in a multivariate analysis. Statistical significance was determined at $p \leq 0$. 05 .

\section{Results}

\subsection{Demographic characteristics of the dentists and its impact on MS pain}

A total number of 365 questionnaires were returned, indicating a response rate of $71.2 \%$ (356/500 dentists). Dentists working in public and private sectors, $25.8 \%$ and $59.8 \%$, respectively and in both sectors $14.3 \%$. The percentage who lived and worked in the urban and rural regions was $91.3 \%$ and $8.7 \%$, respectively. Practice areas included $64 \%$ of general dental practitioners, $12.6 \%$ pediatric dental consultants, $5.1 \%$ prosthodontics specialists, $4.8 \%$ oral surgery specialists, $4.5 \%$ endodontists, $3.7 \%$ orthodontists, and $1.4 \%$ general dental consultants.

The sample mean age was $42 \pm 9.75$ years with $66 \%$ of female dentists. The sample average values were: $23.81 \pm 3.56 \mathrm{~kg} / \mathrm{m}^{2}$ for the body mass index, $6.81 \pm 1.10$ years dentists spent for full-time studying dentistry, and $13.65 \pm 9.44$ years for full-time working experience. Only 2.2 percent of dentists were left-handed. Left-handed dentists used right and the dominant hand during work in $62.5 \%$ and $25.0 \%$, respectively. Only $12.5 \%$ were able to work with both hands. The average number of treated patients was $31.99 \pm 22.82$ per week, and 6.4 patients per day, while $47 \%$ of dentists worked without dental assistant. Finally, the job satisfaction among dentists was $81 \%$.

Relations between occurrences of pain during work with observed demographic characteristics of 
Table 1

Correlation between occurrence of pain during work with the observed demographic characteristics of dentists

\begin{tabular}{|c|c|c|c|c|}
\hline \multirow{2}{*}{\multicolumn{2}{|c|}{ Observed parameters }} & \multirow{2}{*}{\multicolumn{2}{|c|}{ Presence of pain }} & \multirow[t]{2}{*}{ Statistical significance } \\
\hline & & & & \\
\hline Age (years) & $(42 \pm 9.75)$ & $\begin{array}{c}\text { Yes } \\
44 \pm 9\end{array}$ & $\begin{array}{c}\text { No } \\
34 \pm 6\end{array}$ & ${ }^{\mathrm{c}} p<0.001^{*}$ \\
\hline \multirow[t]{2}{*}{ Gender $n(\%)$} & Men & $82(27.9 \%)$ & $39(62.9 \%)$ & ${ }^{\mathrm{a}} p<0.001^{*}$ \\
\hline & Women & $212(72.1 \%)$ & $23(37.1 \%)$ & \\
\hline $\begin{array}{l}\text { Duration of studying } \\
\text { (years) }\end{array}$ & $6.81 \pm 1.10$ & $7 \pm 1.13$ & $6 \pm 0.91$ & ${ }^{\mathrm{b}} p=0.145$ \\
\hline $\begin{array}{l}\text { Years of working } \\
\text { experience (years) }\end{array}$ & $13.65 \pm 9.44$ & $15.89 \pm 9.19$ & $5.85 \pm 6.13$ & ${ }^{\mathrm{b}} p=<0.001 *$ \\
\hline \multirow[t]{2}{*}{ Place of work $n(\%)$} & City & $265(90.1 \%)$ & $60(96.8 \%)$ & ${ }^{\mathrm{a}} p=0.134$ \\
\hline & Village & $29(9.9 \%)$ & $2(3.2 \%)$ & \\
\hline \multirow[t]{2}{*}{ Children $n(\%)$} & Yes & $215(73.1 \%)$ & $8(12.9 \%)$ & ${ }^{\mathrm{a}} p<0.001 *$ \\
\hline & No & $79(26.9 \%)$ & $54(87.1 \%)$ & \\
\hline \multirow[t]{2}{*}{ Specialty $n(\%)$} & Yes & $118(40.1 \%)$ & $5(8.1 \%)$ & ${ }^{\mathrm{a}} p<0.001^{*}$ \\
\hline & No & $176(59.9 \%)$ & $57(91.9 \%)$ & \\
\hline \multirow[t]{7}{*}{ Field of specialization $n(\%)$} & $\begin{array}{c}\text { Pediatrics and } \\
\text { preventive dentistry }\end{array}$ & $45(37.8 \%)$ & $0(0 \%)$ & ${ }^{\mathrm{a}} p<0.001^{*}$ \\
\hline & Endodontic & $11(9.2 \%)$ & $5(83.3 \%)$ & \\
\hline & Periodontology & $11(9.2 \%)$ & $0(0 \%)$ & \\
\hline & Orthodontics & $13(10.9 \%)$ & $0(0 \%)$ & \\
\hline & Prosthetics & $18(15.1 \%)$ & $0(0 \%)$ & \\
\hline & Oral surgery & $16(13.4 \%)$ & $1(16.7 \%)$ & \\
\hline & General dentistry & $5(4.2 \%)$ & $0(0 \%)$ & \\
\hline \multirow[t]{2}{*}{ Job satisfaction $n(\%)$} & Yes & $242(82.3 \%)$ & $49(79 \%)$ & ${ }^{\mathrm{a}} p=0.543$ \\
\hline & No & $52(17.7 \%)$ & $13(21 \%)$ & \\
\hline \multirow[t]{3}{*}{ Type of institution $n(\%)$} & State sector & $83(28.2 \%)$ & $9(14.5 \%)$ & ${ }^{\mathrm{a}} p<0.001^{*}$ \\
\hline & Private practice & $163(55.4 \%)$ & $50(80.6 \%)$ & \\
\hline & Both & $48(16.3 \%)$ & $3(4.8 \%)$ & \\
\hline \multirow[t]{4}{*}{$\mathrm{BMI} n(\%)$} & $<18.5$ & $7(2.4 \%)$ & $2(3.2 \%)$ & $\mathrm{b}_{p}=0.07$ \\
\hline & $18.5-25$ & $190(64.6 \%)$ & $26(41.9 \%)$ & \\
\hline & $25-30$ & $83(28.2 \%)$ & $27(43.5 \%)$ & \\
\hline & $>30$ & $14(4.8 \%)$ & $7(11.3 \%)$ & \\
\hline \multirow{2}{*}{$\begin{array}{l}\text { Dominant working } \\
\text { hand } n(\%)\end{array}$} & Right-handed & $268(97.3 \%)$ & $62(100 \%)$ & ${ }^{\mathrm{a}} p=0.320$ \\
\hline & Left-handed & $8(2.7 \%)$ & $0(0 \%)$ & \\
\hline
\end{tabular}

*Statistically significant; ${ }^{\mathrm{a}} \chi^{2}$-test; ${ }^{\mathrm{b}}$ Mann-Whitney test; ${ }^{\mathrm{c}}$-test.

the dentists are given in Table 1. Occurrence of pain was statistically higher in older dentists, with longer work experience, female dentists and dentists with children $(p \leq 0.01)$. The most affected by pain during work were consultants of preventive and pediatric dentistry $(p \leq 0.01)$. The presence of pain during work is less among subjects who worked in private institutions $(p \leq 0.01)$.

\subsection{Prevalence of work-related MSDs among dentists}

Twenty eight percent of the dentists diagnosed had some type of MSDs. The most common workrelated complaint was MS pain and had a high prevalence $(82.6 \%)$ among dentists. The most commonly affected body regions were the neck (49.5\%) and the lumbar spine (46\%). The first signs of workrelated MS pain appeared after three years of work. Symptoms of carpal tunnel syndrome showed in
$22.8 \%$ dentists. They reported that the following problems affected their hands during or immediately after work: $16 \%$ of them felt loss of normal sensation and problem with coordination, 22.8\% stiffness and numbness, $22.2 \%$ weakness and fatigue. Dentists felt pain and fatigue in their hands frequently after the endodontic interventions (32.3\%), then after tooth extractions (27\%), during work with children $(13.8 \%)$, and after the prosthodontics treatments $(10.7 \%)$. The worst pain dentists felt during work $(49.3 \%)$, then during work breaks $(36.5 \%)$, and after work time (13\%).

\subsection{Body postures and their influence on work-related MS pain}

The different work postures among dentists are the following: $52 \%$ of the dentists were standing and 25\% of them were sitting, while in only $23 \%$ they changed their working position. 
Table 2

Correlation between occurrence of pain during work with the observed working conditions and habits

\begin{tabular}{|c|c|c|c|c|}
\hline \multicolumn{2}{|c|}{ Observed parameters } & \multicolumn{2}{|c|}{ Presence of pain } & \multirow[t]{2}{*}{ Statistical significance } \\
\hline & & Yes & No & \\
\hline \multirow{4}{*}{$\begin{array}{l}\text { Preferred working } \\
\text { position } n(\%)\end{array}$} & Sitting & $74(25.2 \%)$ & $8(12.9 \%)$ & \\
\hline & Standing & $76(25.9 \%)$ & $13(29 \%)$ & \\
\hline & Combining both & & & ${ }^{\mathrm{a}} p=0.035^{*}$ \\
\hline & positions & $144(49 \%)$ & $41(66.1 \%)$ & \\
\hline \multirow{4}{*}{$\begin{array}{l}\text { Therapeutic chair } \\
\text { support } n(\%)\end{array}$} & In lumbar region & $63(28.3 \%)$ & $24(48 \%)$ & ${ }^{\mathrm{a}} p<0.001 *$ \\
\hline & In thoracic region & $5(2.2 \%)$ & $9(18 \%)$ & \\
\hline & $\begin{array}{l}\text { In both, lumbar and } \\
\text { thoracic region }\end{array}$ & $13(5.8 \%)$ & $5(10 \%)$ & \\
\hline & $\begin{array}{l}\text { Does not provide } \\
\text { any support }\end{array}$ & $142(63.7 \%)$ & $12(24 \%)$ & \\
\hline \multirow{2}{*}{$\begin{array}{l}\text { Therapeutic chair } \\
\text { armrest } n(\%)\end{array}$} & Yes & $31(13.5 \%)$ & $13(25.5 \%)$ & ${ }^{\mathrm{a}} p=0.034^{*}$ \\
\hline & No & $198(86.5 \%)$ & $38(74.5 \%)$ & \\
\hline \multirow{2}{*}{$\begin{array}{l}\text { Working in the same position } \\
\text { longer than } 40 \min n(\%)\end{array}$} & Yes & $141(48 \%)$ & $16(25.8 \%)$ & ${ }^{\mathrm{a}} p<0.001^{*}$ \\
\hline & No & $153(52 \%)$ & $46(74.2 \%)$ & \\
\hline \multirow{2}{*}{$\begin{array}{l}\text { Try to work in a proper } \\
\text { body position } n(\%)\end{array}$} & Yes & $218(74.1 \%)$ & $60(96.8 \%)$ & ${ }^{\mathrm{a}} p<0.001^{*}$ \\
\hline & No & $76(25.9 \%)$ & $2(3.2 \%)$ & \\
\hline \multirow{2}{*}{$\begin{array}{l}\text { Discomfort while working in a } \\
\text { certain body positions } n(\%)\end{array}$} & Yes & $255(86.7 \%)$ & $22(35.5 \%)$ & ${ }^{\mathrm{a}} p<0.001^{*}$ \\
\hline & No & $39(13.3 \%)$ & $40(64.5 \%)$ & \\
\hline $\begin{array}{l}\text { The average number of patients } \\
\text { during the working week } \\
\text { (number of patients) }\end{array}$ & $31.99 \pm 22.82$ & $34.70 \pm 22.92$ & $19.13 \pm 17.44$ & ${ }^{\mathrm{b}} p<0.001^{*}$ \\
\hline \multirow{2}{*}{$\begin{array}{l}\text { Working with or without } \\
\text { dental assistant } n(\%)\end{array}$} & Yes & $154(52.4 \%)$ & $34(54.8 \%)$ & ${ }^{\mathrm{a}} p=0.725$ \\
\hline & No & $140(47.6 \%)$ & $28(45.2 \%)$ & \\
\hline
\end{tabular}

*Statistically significant; ${ }^{\mathrm{a}} \chi^{2}$-test; ${ }^{\mathrm{b}}$ Mann-Whitney test.

Association between occurrences of pain during dental work with the observed working conditions and habits are presented in Table 2. The dentists who changed their body postures and $(p \leq 0.05)$ attempted to work in a proper body posture during work $(p \leq 0.01)$ had a statistically significant low rate of MS pain. Also, the occurrences of pain were significantly more prevalent among dentists who used the therapeutic chairs without lumbar support $(p \leq 0.01)$, and without armrest $(p \leq 0.05)$. Dentists who kept the same body posture without a break for a long time had the highest prevalence of MS pain.

\subsection{Work schedule and its effect on MS pain}

Relations between occurrences of pain during work with an average time engagement of the dentist was reported in Table 3. The dentists who had more patients per week had statistically significantly high prevalence of MS pain $(p \leq 0$. 01) but those working with or without a dental assistant has no influence on pain presence ( $p \geq 0$. 05). Long working hours and more working days per week, indicated significantly high rate of reported pain $(p \leq 0.01)$. The occurrence of pain was significantly higher among dentists who do not take a break during work $(p \leq 0.01)$ and who worked with patients between 6 to 8 hours a day $(p \leq 0.05)$. Also, there was a high prevalence of MS pain $(p \leq 0.05)$ in dentists who had bad sitting body postures during work on computer for up to 4 hours a day.

\subsection{Health status of the dentists and its link to MS pain}

Thirty percent of dentists suffered from chronic diseases. Most of them had cardiovascular disease and diabetes with $61.7 \%$ and $21.5 \%$, respectively, and in $16.8 \%$ they had both diseases. Also, they had varicose veins in $23.9 \%$. The frequency of allergic reactions to latex was $63.3 \%$ and to other allergens was $8.9 \%$. Headaches and sleeping problems affected $28.4 \%$ and $23 \%$ of the dentists, respectively. The presence of chronic diseases showed immense impact $(p \leq 0.05)$ on presence of MS pain among dentists. Table 4 describes relation of work-related MS pain to health status of the dentists.

\subsection{Attempt to combat MSDs discomfort among dentists}

Only $16 \%$ of the dentists used massage therapy and $44 \%$ of them exercise regularly. They used magnification devices in only $2.8 \%$ of the cases. 
Table 3

Correlation between occurrence of pain during work with an average time engagement of dentists

\begin{tabular}{|c|c|c|c|c|}
\hline \multicolumn{2}{|l|}{ Observed parameters } & \multicolumn{2}{|c|}{ Presence of pain } & \multirow[t]{2}{*}{ Statistical significance } \\
\hline & & Yes & No & \\
\hline $\begin{array}{l}\text { The average number of patients during the working week } \\
\text { (number of patients) }\end{array}$ & $31.99 \pm 22.82$ & $34.70 \pm 22.92$ & $19.13 \pm 17.44$ & ${ }^{\mathrm{b}} p<0.001 *$ \\
\hline \multirow[t]{2}{*}{ Working with or without dental assistant $n(\%)$} & Yes & $154(52.4 \%)$ & $34(54.8 \%)$ & ${ }^{\mathrm{a}} p=0.725$ \\
\hline & No & $140(47.6 \%)$ & $28(45.2 \%)$ & \\
\hline Length of working time during the day $(\mathrm{h})$ & $7.31 \pm 1.14$ & $7.43 \pm 1.0$ & $6.75 \pm 1.3$ & ${ }^{\mathrm{b}} p<0.001 *$ \\
\hline Number of working days during the week (number of days) & $5.33 \pm 0.55$ & $5.39 \pm 0.56$ & $5.05 \pm 0.38$ & ${ }^{\mathrm{b}} p<0.001 *$ \\
\hline \multirow[t]{3}{*}{ Work with the patients $n(\%)$} & $3-5(h)$ & $20(6.8 \%)$ & $11(7.7 \%)$ & ${ }^{\mathrm{a}} p=0.006^{*}$ \\
\hline & $6-8(h)$ & $166(56.5 \%)$ & $37(59.7 \%)$ & \\
\hline & $8+(h)$ & $108(36.7 \%)$ & $14(22.6 \%)$ & \\
\hline \multirow[t]{3}{*}{ Conversation with the patients $n(\%)$} & $0-1(h)$ & $61(20.7 \%)$ & $1(1.6 \%)$ & ${ }^{\mathrm{a}} p<0.001 *$ \\
\hline & $2-3(h)$ & $224(76.2 \%)$ & $60(96.8 \%)$ & \\
\hline & $3-4(h)$ & $9(3.1 \%)$ & $1(1.6 \%)$ & \\
\hline \multirow[t]{3}{*}{ Break time between interventions $n(\%)$} & $0(\mathrm{~h})$ & $203(69 \%)$ & $9(14.5 \%)$ & ${ }^{\mathrm{a}} p<0.001 *$ \\
\hline & $1-2(h)$ & $85(28.9 \%)$ & $52(83.9 \%)$ & \\
\hline & $3-4(h)$ & $6(2 \%)$ & $1(1.6 \%)$ & \\
\hline \multirow[t]{3}{*}{ Work on the computer $n(\%)$} & $0(\mathrm{~h})$ & $49(16.7 \%)$ & $2(3.2 \%)$ & ${ }^{\mathrm{a}} p=0.023 *$ \\
\hline & $1-4(h)$ & $165(56.1 \%)$ & $40(64.5 \%)$ & \\
\hline & $5+(\mathrm{h})$ & $80(27.2 \%)$ & $20(32.3 \%)$ & \\
\hline
\end{tabular}

*Statistically significant; ${ }^{\mathrm{a}} \chi^{2}$-test; ${ }^{\mathrm{b}}$ Mann-Whitney test.

Table 4

Correlation between occurrence of pain during work with the health status of the dentists

\begin{tabular}{|c|c|c|c|c|}
\hline \multicolumn{2}{|c|}{ Observed parameters } & \multicolumn{2}{|c|}{ Presence of pain } & \multirow[t]{2}{*}{ Statistical significance } \\
\hline & & Yes & No & \\
\hline Chronic diseases $n(\%)$ & Yes & $105(35.7 \%)$ & $4(6.5 \%)$ & ${ }^{\mathrm{a}} p<0.001 *$ \\
\hline \multirow[t]{3}{*}{ Allergies $n(\%)$} & No & $189(64.3 \%)$ & $58(93.5 \%)$ & \\
\hline & Yes & $85(28.9 \%)$ & $5(8.1 \%)$ & ${ }^{\mathrm{a}} p=0.01 *$ \\
\hline & No & $209(71.1 \%)$ & $57(91.9 \%)$ & \\
\hline \multirow[t]{4}{*}{ Type of allergies $n(\%)$} & Latex & $56(65.9 \%)$ & $1(20 \%)$ & ${ }^{\mathrm{a}} p=0.02^{*}$ \\
\hline & Penicillin & $10(11.8 \%)$ & $3(60 \%)$ & \\
\hline & Pollen & $11(12.9 \%)$ & $1(20 \%)$ & \\
\hline & $\begin{array}{l}\text { Combination of } \\
\text { more allergens }\end{array}$ & $8(9.4 \%)$ & $0(0 \%)$ & \\
\hline \multirow[t]{3}{*}{ Family anamnesis $n(\%)$} & $\begin{array}{l}\text { Locomotors system } \\
\text { illnesses }\end{array}$ & $39(17.3 \%)$ & $4(12.1 \%)$ & ${ }^{\mathrm{a}} p=0.056$ \\
\hline & $\begin{array}{c}\text { Cardiovascular system } \\
\text { illnesses }\end{array}$ & $107(47.6 \%)$ & $23(69.7 \%)$ & \\
\hline & Both & $79(35.1 \%)$ & $6(18.2 \%)$ & \\
\hline
\end{tabular}

*Statistically significant; ${ }^{\mathrm{a}} \chi^{2}$-test; ${ }^{\mathrm{b}}$ Mann-Whitney test.

Magnification loupes were the most commonly used among magnification devices (90\%). Dentists mostly used them while performing endodontic treatment (90\%) and when doing periodontal surgery $(10 \%)$. Table 5 presents relations of the preventive measures and used equipment to MS pain. Among all preventive measures, physical activity has an immense influence on the reduction of MS pain among dentists $(p \leq 0.01)$. Also the dentists who had MS pain used massage treatments more often than the others dentists $(p \leq 0.01)$.

\subsection{Consequences of work-related MS pain, injures and infections on dentist's work ability}

The results in Table 6 revealed MS pain has an immense impact on work habits among dentists. The frequency of work breaks and absence were high. When seeking medical treatments they used analgesics to ease MS pain. Dentists used analgesics in $47.3 \%$ of the case and they were seeking medical treatment in $39 \%$ in order to combat the MSDs 
Table 5

Correlation between occurrence of MS pain during work with the preventive measures

\begin{tabular}{|c|c|c|c|c|}
\hline \multicolumn{2}{|c|}{ Observed parameters } & \multicolumn{2}{|c|}{ Presence of pain } & \multirow[t]{2}{*}{ Statistical significance } \\
\hline & & Yes & No & \\
\hline \multirow{2}{*}{$\begin{array}{l}\text { Protective } \\
\quad \text { equipment } n(\%)\end{array}$} & Yes & $275(93.5 \%)$ & $60(96.8 \%)$ & ${ }^{\mathrm{a}} p=0.551$ \\
\hline & No & $19(6.5 \%)$ & $2(3.2 \%)$ & \\
\hline \multirow{5}{*}{$\begin{array}{l}\text { Type of protective } \\
\text { equipment } n(\%)\end{array}$} & Gloves & $36(13.1 \%)$ & $4(6.7 \%)$ & ${ }^{\mathrm{a}} p=0.145$ \\
\hline & Visor & $8(2.9 \%)$ & $1(1.7 \%)$ & \\
\hline & Protective glasses and gloves & $0(0 \%)$ & $1(1.7 \%)$ & \\
\hline & Protective mask and gloves & $166(60.4 \%)$ & $36(63.3 \%)$ & \\
\hline & Glasses, gloves and mask & $65(23.6 \%)$ & $16(23.7 \%)$ & \\
\hline \multirow[t]{2}{*}{ Optical devices $n(\%)$} & Yes & $6(2 \%)$ & $4(6.5 \%)$ & ${ }^{\mathrm{a}} p=0.078$ \\
\hline & No & $287(98 \%)$ & $58(93.5 \%)$ & \\
\hline \multirow{2}{*}{$\begin{array}{l}\text { Dental procedures in } \\
\text { which use optical } \\
\text { devices } n(\%)\end{array}$} & Endodontic & $68(100 \%)$ & $3(75 \%)$ & ${ }^{\mathrm{a}} p=0.40$ \\
\hline & Periodontal surgery & $0(0 \%)$ & $1(25 \%)$ & \\
\hline \multirow[t]{2}{*}{ Physical activity $n(\%)$} & Yes & $88(29.9 \%)$ & $54(87.1 \%)$ & ${ }^{\mathrm{a}} p<0.001^{*}$ \\
\hline & No & $206(70.1 \%)$ & $8(12.9 \%)$ & \\
\hline \multirow{3}{*}{$\begin{array}{l}\text { Frequency of physical } \\
\text { activity } n(\%)\end{array}$} & Everyday & $7(7.9 \%)$ & $1(1.9 \%)$ & ${ }^{\mathrm{a}} p=0.253$ \\
\hline & 3 times per week & $37(41.6 \%)$ & $27(50 \%)$ & \\
\hline & Once a week & $45(50.6 \%)$ & $26(48.1 \%)$ & \\
\hline \multirow[t]{2}{*}{ Massage treatments $n(\%)$} & Yes & $56(19 \%)$ & $1(1.6 \%)$ & ${ }^{\mathrm{a}} p<0.001 *$ \\
\hline & No & $238(81 \%)$ & $61(98.4 \%)$ & \\
\hline \multirow{3}{*}{$\begin{array}{l}\text { Frequency of massage } \\
\quad \text { treatments } n(\%)\end{array}$} & Once a week & $4(7.3 \%)$ & $0(0 \%)$ & ${ }^{\mathrm{a}} p=0.07$ \\
\hline & Once a month & $8(14.5 \%)$ & $1(100 \%)$ & \\
\hline & Occasionally & $43(78.2 \%)$ & $0(0 \%)$ & \\
\hline
\end{tabular}

*statistically significant; ${ }^{\text {a }} \chi^{2}$-test.

discomfort. Musculoskeletal diseases, varicose veins, headache, problems with sleeping and symptoms that were indicative of carpal tunnel syndrome, are correlated with MS pain during work $(p<0.001)$ (Table 6).

There was $17 \%$ of injured dentists in the workplace during the last year. The most frequent injuries were the following: $45.7 \%$ stab, $34.3 \%$ cuts, and $20 \%$ patients bites. Forty percent of dentists had respiratory infections, while eye infections and injuries were occasional with $40 \%$ and $16.6 \%$, respectively. Associations of work-related injuries and infection with a presence of MS pain are presented in Table 7. Dentists who had work-related injuries and infection had significantly high prevalence of MS pain $(p \leq 0.01)$ but different types of injuries did not show statistical significance $(p \geq 0.05)$.

\subsection{The risk and protective factors of MS pain among dentists}

To define the risk and protective factors univariate and multivariate logistic analysis were used and the results are presented in Table 8 . The multivariate analysis showed that risk factors for an onset of the musculoskeletal pain symptoms were the following: age $(\mathrm{OR}=0.826)$, a female gender $(\mathrm{OR}=0.248)$, working long hours during the week $(\mathrm{OR}=0.126)$, a high number of treated patients $(\mathrm{OR}=0.961)$, presence of the chronic diseases $(\mathrm{OR}=5.480)$, working in the same position longer than $40 \mathrm{~min}$ $(\mathrm{OR}=23.143)$, discomfort during work in a certain body positions $(\mathrm{OR}=10.826)$, having varicose veins $(\mathrm{OR}=8.063)$ and headaches $(\mathrm{OR}=10.0551)$, hands weakness and fatigue $(\mathrm{OR}=12.241)$ and problems with sleeping $(\mathrm{OR}=3.832)$.

Also the protective factors were the following: changing body postures during work $(\mathrm{OR}=2.028)$, use of therapeutic chairs with support $(\mathrm{OR}=0.596)$, working in a proper body position $(\mathrm{OR}=0.83)$ and physical activity $(\mathrm{OR}=0.301)$.

Presence of pain increases the needs for massage treatments $(\mathrm{OR}=16.018)$, higher frequency of physical activity $(\mathrm{OR}=10.902)$, and more frequent breaks during work $(\mathrm{OR}=6.518)$.

\section{Discussion}

The results of the study indicated that $82.6 \%$ of Serbian dentists suffered from work-related musculoskeletal pain. The data from relevant literature showed that in other countries prevalence of musculoskeletal pain among dentist ranged from $64 \%$ to 93\% [7, 8]. Also, the most common body regions affected by pain were the neck $(49.5 \%)$ and lumbar back (46\%). The previous studies show the 
Table 6

Consequences and characteristics of MS pain

\begin{tabular}{|c|c|c|c|c|}
\hline \multicolumn{2}{|c|}{ Observed parameters } & \multicolumn{2}{|c|}{ Presence of pain } & \multirow[t]{2}{*}{ Statistical significance } \\
\hline & & Yes & No & \\
\hline $\begin{array}{l}\text { First time of appearance of } \\
\text { pain symptom (years) }\end{array}$ & $3.78 \pm 3.56$ & $3.78 \pm 3.58$ & $4.00 \pm 2.00$ & ${ }^{\mathrm{b}} p=0.483$ \\
\hline \multirow{2}{*}{$\begin{array}{l}\text { Daily work interference } \\
\text { because of pain } n(\%)\end{array}$} & Yes & $175(59.7 \%)$ & $0(0 \%)$ & ${ }^{\mathrm{a}} p<0.001 *$ \\
\hline & No & $118(40.3 \%)$ & $62(100 \%)$ & \\
\hline \multirow{2}{*}{$\begin{array}{l}\text { Breaks during the work } \\
\text { because of pain } n(\%)\end{array}$} & Yes & $130(44.2 \%)$ & $0(0 \%)$ & ${ }^{\mathrm{a}} p<0.001 *$ \\
\hline & No & $164(55.8 \%)$ & $62(100 \%)$ & \\
\hline \multirow{2}{*}{$\begin{array}{l}\text { Shortened working hours } \\
\text { due to pain } n(\%)\end{array}$} & Yes & $15(5.1 \%)$ & $0(0 \%)$ & ${ }^{\mathrm{a}} p=0.083$ \\
\hline & No & $278(94.9 \%)$ & $62(100 \%)$ & \\
\hline \multirow{2}{*}{$\begin{array}{l}\text { Absent from work } \\
\text { because of pain } n(\%)\end{array}$} & Yes & $45(15.4 \%)$ & $0(0 \%)$ & ${ }^{\mathrm{a}} p<0.001 *$ \\
\hline & No & $248(84.6 \%)$ & $62(100 \%)$ & \\
\hline \multirow[t]{4}{*}{ Length of absence from work $n(\%)$} & 1 day & $7(14 \%)$ & $0(0 \%)$ & ${ }^{\mathrm{a}} p=0.564$ \\
\hline & $2-5$ days & $23(46 \%)$ & $0(0 \%)$ & \\
\hline & 5-15 days & $16(32 \%)$ & $1(100 \%)$ & \\
\hline & Over a month & $4(8 \%)$ & $0(0 \%)$ & \\
\hline \multirow[t]{2}{*}{ Need for medical care $n(\%)$} & Yes & $138(46.9 \%)$ & $1(1.6 \%)$ & ${ }^{\mathrm{a}} p<0.001^{*}$ \\
\hline & No & $156(53.1 \%)$ & $61(98.4 \%)$ & \\
\hline \multirow[t]{2}{*}{ Type of medical care $n(\%)$} & General practitioner & $34(24.6 \%)$ & $0(0 \%)$ & ${ }^{\mathrm{a}} p=0.568$ \\
\hline & Physiatrist & $104(75.4 \%)$ & $1(100 \%)$ & \\
\hline \multirow[t]{2}{*}{ Use of analgesics $n(\%)$} & Yes & $163(55.4 \%)$ & $3(5.3 \%)$ & ${ }^{\mathrm{a}} p<0.001^{*}$ \\
\hline & No & $131(44.6 \%)$ & $54(94.7 \%)$ & \\
\hline \multirow[t]{3}{*}{ Type of analgesics $n(\%)$} & $\begin{array}{c}\text { Derivatives of } \\
\text { acetylsalicylic acid }\end{array}$ & $67(40.9 \%)$ & $0(0 \%)$ & ${ }^{\mathrm{a}} p=0.236$ \\
\hline & NSAID & $76(46.3 \%)$ & $1(50 \%)$ & \\
\hline & Paracetamol & $21(12.8 \%)$ & $1(50 \%)$ & \\
\hline \multirow[t]{4}{*}{ Frequency of use of analgesics $n(\%)$} & 1-2 times per months & $35(21.5 \%)$ & $2(100 \%)$ & ${ }^{\mathrm{a}} p=0.072$ \\
\hline & Once a week & $60(36.8 \%)$ & $0(0 \%)$ & \\
\hline & 2-4 times per week & $55(33.7 \%)$ & $0(0 \%)$ & \\
\hline & Everyday & $13(8 \%)$ & $0(0 \%)$ & \\
\hline \multirow[t]{2}{*}{ Musculoskeletal diseases $n(\%)$} & Yes & $100(34 \%)$ & $1(1.6 \%)$ & ${ }^{\mathrm{a}} p<0.001 *$ \\
\hline & No & $194(66 \%)$ & $61(98.4 \%)$ & \\
\hline \multirow[t]{4}{*}{ Type of musculoskeletal disease $n(\%)$} & Spine deformities & $43(42.6 \%)$ & $0(0 \%)$ & ${ }^{\mathrm{a}} p=0.056$ \\
\hline & Rheumatic diseases & $33(32.7 \%)$ & $0(0 \%)$ & \\
\hline & Osteoporosis & $14(13.9 \%)$ & $0(0 \%)$ & \\
\hline & Spinal disc herniation & $11(10.9 \%)$ & $1(100 \%)$ & \\
\hline \multirow[t]{2}{*}{ Varicose veins $n(\%)$} & Yes & $84(28.6 \%)$ & $1(1.6 \%)$ & ${ }^{\mathrm{a}} p<0.001 *$ \\
\hline & No & $210(71.4 \%)$ & $61(98.4 \%)$ & \\
\hline \multirow[t]{2}{*}{ Headache $n(\%)$} & Yes & $100(34 \%)$ & $1(1.6 \%)$ & ${ }^{\mathrm{a}} p<0.001 *$ \\
\hline & No & $194(66 \%)$ & $61(98.4 \%)$ & \\
\hline \multirow[t]{2}{*}{ Problems with sleeping $n(\%)$} & Yes & $79(26.9 \%)$ & $3(4.8 \%)$ & ${ }^{\mathrm{a}} p<0.001^{*}$ \\
\hline & No & $215(73.1 \%)$ & $59(95.2 \%)$ & \\
\hline \multicolumn{5}{|l|}{$\begin{array}{l}\text { Symptoms indicative of } \\
\text { carpal tunnel syndrome }\end{array}$} \\
\hline \multirow{2}{*}{$\begin{array}{l}\text { Loss of coordination and normal } \\
\text { sensation in the hands } n(\%)\end{array}$} & Yes & $57(19.4 \%)$ & $0(0 \%)$ & ${ }^{\mathrm{a}} p<0.001 *$ \\
\hline & No & $237(80.6 \%)$ & $62(100 \%)$ & \\
\hline \multirow{2}{*}{$\begin{array}{l}\text { Stiffness and numbness in the } \\
\text { area of the hands } n(\%)\end{array}$} & Yes & $81(27.6 \%)$ & $0(0 \%)$ & ${ }^{\mathrm{a}} p<0.001 *$ \\
\hline & No & $213(72.4 \%)$ & $62(100 \%)$ & \\
\hline \multirow{2}{*}{$\begin{array}{l}\text { Increased fatigue in the } \\
\text { area of the hands } n(\%)\end{array}$} & Yes & $78(26.5 \%)$ & $1(1.6 \%)$ & ${ }^{\mathrm{a}} p<0.001 *$ \\
\hline & No & $216(73.5 \%)$ & $61(98.4 \%)$ & \\
\hline
\end{tabular}

*Statistically significant; ${ }^{\mathrm{a}} \chi^{2}$-test; ${ }^{\mathrm{b}}$ Mann-Whitney test.

prevalence of neck pain from $19.8 \%$ to $85 \%$, while the prevalence of back pain is $36.3 \%$ to $60.1 \%$ [8], which is in a range with our results.

Also, the symptoms which are indicative of carpal tunnel syndrome (loss of coordination, stiffness, numbness and increased fatigue in the area of the fingers, hands, arms, forearms and shoulders), were highly represented among dentists and according to the results of multivariate logistic analysis, they were significantly associated with an appearance of pain during dental work.

In the studies from other countries, different measurement tools were used in order to determine musculoskeletal symptoms. In many studies a 
Table 7

Correlation between occurrence of pain during work with infections and injuries at work

\begin{tabular}{ccccc}
\hline \multirow{2}{*}{ Observed parameters } & & \multicolumn{2}{c}{ Presence of pain } & \multirow{2}{*}{ Statistical significance } \\
\cline { 2 - 4 } & & Yes & No & \\
\hline Injuries during work $n(\%)$ & Yes & $60(20.4 \%)$ & $0(0 \%)$ & ${ }^{\mathrm{a}} p<0.001^{*}$ \\
& No & $234(79.6 \%)$ & $62(100 \%)$ & \\
Type of injuries $n(\%)$ & Stab & $32(46.4 \%)$ & $0(0 \%)$ & ${ }^{\mathrm{a}} p=0.378$ \\
& Cuts & $23(33.3 \%)$ & $1(100 \%)$ & \\
Eye infection caused by & Bites & $14(20.3 \%)$ & $0(0 \%)$ & \\
professional work $n(\%)$ & Yes & $56(19 \%)$ & $3(4.8 \%)$ & ${ }^{\mathrm{a}} p=0.004^{*}$ \\
Eye injury caused by & No & $238(81 \%)$ & $59(95.2)$ & \\
professional work $n(\%)$ & Yes & $28(9.5 \%)$ & $1(1.6 \%)$ & ${ }^{a} p=0.04^{*}$ \\
Respiratory infection $n(\%)$ & Yes & $266(90.5 \%)$ & $61(98.4 \%)$ & \\
& No & $131(44.6 \%)$ & $16(25.8 \%)$ & ${ }^{a} p=0.006^{*}$ \\
\end{tabular}

*Statistically significant; ${ }^{\mathrm{a}} \chi^{2}$-test.

Table 8

Risk factors for the occurrence of pain during work among dentists

\begin{tabular}{|c|c|c|c|c|}
\hline \multirow[t]{2}{*}{ Observed parameters } & \multicolumn{2}{|c|}{ Univariant logistic regression } & \multicolumn{2}{|c|}{ Multivariant logistic regression } \\
\hline & $\mathrm{OR}(95 \% \mathrm{CI})$ & Significance & OR $(95 \% \mathrm{CI})$ & Significance \\
\hline Age & $0.837(0.795-0.880)$ & $p<0.001^{*}$ & $0.826(0.696-0.981)$ & $p=0.029^{*}$ \\
\hline Gender & $0.228(0.128-0.405)$ & $p<0.001^{*}$ & $0.248(0.093-0.662)$ & $p=0.005^{*}$ \\
\hline Years of working experience & $0.831(0.785-0.881)$ & $p<0.001^{*}$ & $1.072(0.901-1.274)$ & $p=0.434$ \\
\hline Children & $18.370(8.371-40.316)$ & $p<0.001^{*}$ & $4.358(1.595-11.911)$ & $p=0.004^{*}$ \\
\hline BMI & $1.877(1.248-2.821)$ & $p=0.013^{*}$ & $1.425(0.702-2.892)$ & $p=0.327$ \\
\hline Specialty & $7.643(2.975-19.634)$ & $p<0.001^{*}$ & $10.484(2.561-42.914)$ & $p=0.001^{*}$ \\
\hline $\begin{array}{l}\text { Preferred working position } \\
\text { (sitting/standing) }\end{array}$ & $1.631(1.117-2.381)$ & $p=0.035^{*}$ & $2.028(1.201-3.425)$ & $p=0.008^{*}$ \\
\hline Therapeutic chair support & $0.610(0.486-0.766)$ & $p<0.001^{*}$ & $0.596(0.434-0.820)$ & $p=0.001^{*}$ \\
\hline Therapeutic chair armrest & $0.458(0.219-0.954)$ & $p=0.034^{*}$ & $1.271(0.429-3.768)$ & $p=0.665$ \\
\hline $\begin{array}{l}\text { Number of working days during } \\
\text { the week }\end{array}$ & $0.607(0.476-0.773)$ & $p<0.001^{*}$ & $0.928(0.552-1.560)$ & $p=0.779$ \\
\hline $\begin{array}{l}\text { Length of working time during } \\
\text { the day }\end{array}$ & $0.212(0.101-0.446)$ & $p<0.001^{*}$ & $0.126(0.037-0.427)$ & $p=0.001^{*}$ \\
\hline Time of working with the patient & $0.501(0.315-0.796)$ & $p=0.006^{*}$ & $0.582(0.210-1.617)$ & $p=0.299$ \\
\hline $\begin{array}{l}\text { Time of conversation with the } \\
\text { patients }\end{array}$ & $3.166(1.454-6.894)$ & $p<0.001^{*}$ & $2.136(0.524-8.713)$ & $p=0.290$ \\
\hline Break between interventions & $6.897(3.805-12.500)$ & $p<0.001^{*}$ & $6.518(2.588-16.417)$ & $p<0.001^{*}$ \\
\hline Work on the computer & $1.597(1.024-2.489)$ & $p=0.039^{*}$ & $1.289(0.665-2.498)$ & $p=0.452$ \\
\hline Chronic diseases & $8.056(2.845-22.812)$ & $p<0.001^{*}$ & $5.480(1.855-16.187)$ & $p=0.002^{*}$ \\
\hline Musculoskeletal disease & $31.443(4.295-230.17)$ & $p<0.001^{*}$ & $23.143(3.078-174.041)$ & $p=0.002^{*}$ \\
\hline Allergies & $4.636(1.796-11.968)$ & $p=0.002^{*}$ & $3.049(1.111-8.365)$ & $p=0.030^{*}$ \\
\hline Eye infection & $4.627(1.399-15.302)$ & $p=0.012^{*}$ & $2.318(0.642-8.362)$ & $p=0.199$ \\
\hline Respiratory infection & $2.311(1.251-4.268)$ & $p=0.007^{*}$ & $1.378(0.693-2.740$ & $p=0.360$ \\
\hline Wearing glasses or contact lenses & $2.139(1.217-3.761)$ & $p=0.008^{*}$ & $1.684(0.904-3.138)$ & $p=0.101^{*}$ \\
\hline $\begin{array}{l}\text { Working in the same position } \\
\text { longer than } 40 \mathrm{~min}\end{array}$ & $2.650(1.435-4.892)$ & $p=0.002^{*}$ & $2.512(1.218-5.178)$ & $p=0.013^{*}$ \\
\hline $\begin{array}{l}\text { Try to work in a proper body } \\
\text { position }\end{array}$ & $0.096(0.023-0.401)$ & $p<0.001^{*}$ & $0.83(0.018-0.378)$ & $p<0.001^{*}$ \\
\hline $\begin{array}{l}\text { Discomfort while working in a } \\
\text { certain body positions }\end{array}$ & $11.888(6.396-22.096)$ & $p<0.001^{*}$ & $10.826(5.380-21.783)$ & $p<0.001^{*}$ \\
\hline The average number of patients & $0.953(0.934-0.972)$ & $p<0.001^{*}$ & $0.961(0.942-0.981)$ & $p<0.001^{*}$ \\
\hline Physical activity & $0.063(0.029-0.139)$ & $p<0.001^{*}$ & $0.301(0.108-0.839)$ & $p=0.022^{*}$ \\
\hline Frequency of physical activity & $26.490(9.353-75.025)$ & $p<0.001^{*}$ & $10.902(2.926-40.616)$ & $p<0.001^{*}$ \\
\hline Massage treatments & $14.353(1.948-105.76)$ & $p=0.009^{*}$ & $16.018(2.102-122.048)$ & $p=0.007^{*}$ \\
\hline Varicose veins & $24.400(3.328-178.87)$ & $p=0.002^{*}$ & $8.063(1.044-62.254)$ & $p=0.045^{*}$ \\
\hline Headache & $31.443(4.295-230.17)$ & $p<0.001^{*}$ & $10.0551(1.379-80.737)$ & $p=0.023^{*}$ \\
\hline Fatigue in the area of the hands & $22.028(3.003-161.60)$ & $p=0.002^{*}$ & $12.241(1.629-92.003)$ & $p=0.015^{*}$ \\
\hline Problems with sleeping & $7.226(2.202-23.714)$ & $p<0.001^{*}$ & $3.832(1.114-13.176)$ & $p=0.033^{*}$ \\
\hline
\end{tabular}

$\mathrm{OR}$ - odds ratio; $\mathrm{CI}$ - confidence interval; ${ }^{*} p<0.05$ statistically significant. 
modification of standardized Nordic Questionnaire were used. However, this method only determines location and presence of MSDs and MS pain [21, 22]. Questionnaires specially designed for the current study in addition to location and presence of MS pain, authors wanted to identify the main risk factors for MS pain during dental work, to assess the consequences of these factors on dental work, and to identify preventive measures of MS pain (Appendix 1).

Pilot surveys and questionnaires also appear to be a widely used method of measuring the occurrence of MS pain [23, 24]. Although this self-reported method may have limitations, such as the bias of respondents, it was chosen because it represents a cheap, convenient, widely used available and effective method [23, 24].

The occurrence of pain was significantly higher among women dentists, which is consistent with the results of other studies [25-27]. Also the results show the occurrence of MS pain was significantly higher in older dentists and in dentists with longer working experience. The reason of these findings most probable is the cumulative effect of MS pain on the development of MSDs. A study by Puirene, et. al. showed that advancing years had a significant negative impact on dentist's musculoskeletal health [17]. In contrary, some authors found that pain in dentistry occurred more frequently among younger dentists because experienced dentists learn how to work in adjusted postures to avoid pain. Alternatively, the other group of authors had an opinion that dentists had left the profession due to pain [22, 23].

Prevalence of pain during work was the highest among specialists of preventive and pediatric dentistry, which is in accordance with the results of Newton et al. [28]. This result can be explained by the fact that work with younger patients can be physically and mentally extremely demanding. Among children patients, levels of anxiety and fear caused by dental intervention are frequently high and work with these children requires a higher level of operator's body flexion. Unnatural working posture with time, could lead to the development of WMSDs.

We found the prevalence of pain was significantly higher among dentist who worked in non-ergonomic environment, used therapeutic chairs without lumbar support and armrests. It is well established that use of ergonomically designed equipment reduce muscular load and fatigue during work and can reduce risk of developing WMSDs [16, 18, 19]. On the contrary, the results from this study pointed out that previous knowledge about WMSDs was not well disseminated and implemented in a daily dental work.

In this study the lowest prevalence of MS pain was among dentists who changed their working position during work. In a standing position, different groups of muscles were activated compared to those in a sitting position while performing dental work [29]. By combining both, sitting and standing, excellent work can be achieved and the different groups of muscles are less loaded. Dynamic work is less tiring and more efficient than static work. These findings are in accordance with electromyography and inclination of the study by Pejcic at al. where the results showed importance for changing working position in order to reduce fatigue and MS pain among dentists [30]. Furthermore, the selfrated pain was significantly higher among dentists who worked in the same position for longer than 40 minutes. Taken together, the alterations between these two postures, sitting and standing, should be highly suggested as preventive measure of MS pain to all dentists. This can be achieved by implementing the body postures alteration principle to the dental educational system, as early adopted good working habits are the best strategy in prevention of MSDs. Likewise, the body postures alteration principle was recommended by the American Dental Association (ADA) and European Society of Dental Ergonomics (ESDE) [31].

Current studies showed dentists with poor general health had higher prevalence of MS pain and indicated that good general health of dentists is a precondition to work without MS pain. In accordance with the above mentioned the results of multivariate logistic regression analysis indicated that dentists with varicose veins had high prevalence of MS pain. Also it is well known fact, dentistry is a highstress profession and the most frequent stress-related consequences are sleeping problems and headaches [32-34]. The results showed dentists who had sleep problems reported more frequent headaches and had a higher prevalence of self-rated MS pain. Literature suggests that psychological factors and emotional stress play key roles in the occurrence of WMSDs [35]. High level of stress in dentistry is caused by nature of clinical work, bad working environment, working with nervous and anxious patients, dental procedures which often cause pain to patient. Time pressure, often poor atmosphere in the workplace caused by problematic interpersonal relationships were also contributing factors of stress and MS pain [36]. Furthermore, long exposure to allergenic 
chemicals which can be found in many products used in the dental workplaces causes allergies in dentists [37]. Dental professionals who participated in the study have the highest prevalence of allergies to latex.

Dental work can be defined as very intensive and there are many dentists who work in more than one institution with long working hours per day [17]. We found that dentists who had longer working hours, high number of patients and more working days per week also had a higher prevalence of MS pain. We strongly suggest that adequate workflow organizations with periodically rest breaks during work are useful preventive measure for reducing MS pain among dental professionals.

In this study, use of the magnification devices among dentists was very rare and had no influence on the prevalence of MS pain. The most likely reasons for this outcome are their high prices, long-time adjustments and insufficient training among Serbian dentists, even though it is well know that usage of magnification devices can improve working posture and reduce MS pain [18].

The presence of MS pain during dental work can decrease concentration, and consequently cause work-related injuries. The most common reported injuries in this study were stab and cuts with dental instruments and bites by patients. Also there were a large number of dentists who use protective equipment. However, we did not find a direct influence of usage of protective equipment on prevalence of work-related MS pain among dentists. MS pain is a very serious psycho-social problem, causing reduced efficiency and satisfaction among dentists. Dentists with MS pain had significantly higher interruption in a daily work, breaks during the work and absenteeism. Also the presence of MS pain had a significant influence on frequent analgesic use and seeking for medical care among dentists. During work, dentists should be fully committed to their patients and occurrences of MS pain during work can cause serious consequences.

Until now prevention strategies in reduction of MS pain among dentists haven't been measured. In current studies, the most effective preventive measures were regular physical activity and massage treatments. As physical activities have a positive influence on musculoskeletal system, improving flexibility, coordination, and muscular strength our recommendations are that physical activities should be adjusted to work schedule and physical characteristics of dentists.

\subsection{Limitations to the study}

Self-reported questionnaire was designed by researchers and as a method has limitations, such as exaggeration, fear to revile private details and other various biases may affect the results. Statistical sample size also affects the results in this study. Furthermore, response bias may occur in that dentists with MSDs may be more likely to answer the survey.

\section{Conclusion}

The questionnaires exclusively developed by authors can serve as a new and reliable test instrument for identification of risk and protective factors of MS pain in dentistry and also to document and evaluate self-reported MS pain during work. This method can be widely used in further research and make huge contribution and improvement in science of dental ergonomic.

MS pain had high prevalence and it was the most common symptom of WMSDs among Serbian dentists. The results indicated that general health of dentists and workflow organization have a significant impact on presence of MS pain. In the higher risk for development of MS pain are older dentists and especially females who suffer from chronic diseases and/or who had long working hours per week and/or with high frequency of treated patients. In everyday life, dentists should implement regular physical activities and massage treatments, which were the most effective preventive measures in this study. Furthermore, by combining correct sitting and standing positions during work with adequate use of ergonomically designed equipment dentists can significantly reduce MS pain. Finally, an adequate workflow organization is an imperative preventive measure for reducing MS pain and development of WMSDs.

The above mentioned data should widely disseminate to all dentists and implement in the educational system which will be the best preventive measure to combat MS pain and development of WMSDs among dentists.

\section{Acknowledgments}

Authors would like to thank all subjects for participating in this study. The work on this project was supported by the Ministry of Education and Science, Republic of Serbia, research grant \# 41008. 


\section{Conflict of interest}

None to report.

\section{References}

[1] Hayes M, Cockrell D, Smith D. A systematic review of musculoskeletal disorders among dental professionals. Int J Dent Hygiene 2009;7:159-65.

[2] Valachi B, Valachi K. Mechanisms leading to musculoskeletal disorders in dentistry. J Am Dent Assoc 2003;134:1344-50.

[3] Alexopoulos EC, Stathi IC, Charizani F. Prevalence of musculoskeletal disorders in dentists. BMC Musculoscelet Disord 2004;5:16.

[4] Waddell G. Biopsychological analysis of low back pain. Ballieres Clinical Rheum 1992;6:523-27.

[5] Fish DR, Morris-Allen DM. Musculoskeletal disorders in dentists. N Y State Dent J 1998;64:44-8.

[6] Ratzon NZ, Yaros T, Mizlik A, Kanner T. Musculoskeletal symptoms among dentists in relation to work posture. Work 2000;15:153-8.

[7] Puriene A, Janulyte V, Musteikyte M, Bendinskaite R. General health of dentists. Literature review. Stomatologija 2007;9:10-20.

[8] Hayes M, Smith D, Cockrell D. An international review of musculoskeletal disorders in the dental hygiene profession. Int Dent J 2010;60:343-52.

[9] Hayes M, Taylor JA, Smith D. Predictors of work-related musculoskeletal disorders among dental hygienists. Int $\mathbf{J}$ Dent Hygiene 2012;6(4):265-9.

[10] World Health Organization. Identification and control of work-related diseases report of a WHO expert committee. Publisher Geneva" World Health Organization Albany, NY" WHO Publications Centre USA, 1985.

[11] Armstrong TJ. Ergonomics and cumulative trauma disorders. Hand Clin 1986;2:553-65.

[12] McGill S, Hughson R, Parks K. Lumbar erector spinae oxygenation during prolonged contractions; implications for prolonged work. Ergonomics 2000;43:486-93.

[13] Biller FR. Occupational hazards in dental practice. Oral Hyg 1946;36:11-94.

[14] Akesson I, Balogh I, Hansson G-Å. Physical workload in neck, shoulders and wrists/hands in dental hygienists during a work-day. Appl Ergon 2012;43:803-11.

[15] Finkbeiner BL. Four Handed Dentistry Revisited. J Cont Dent Prac 2000;1(4):1-9.

[16] Haddad O, Sanjari MA, Amirfazli A, Narimani R, Parnianpour M. Trapezius Muscle Activity in using Ordinary and Ergonomically Designed Dentistry Chairs. Int J Occup Environ Med 2012;3(2):76-83.

[17] Puriene A, Aleksejuninene J, Petrauskiene J, Balciubniene I, Janulyte V. Self-reported occupational health issues among Lithuanian dentists. Industrial Health 2008;48:369-74.

[18] Hayers M, Osmotherly P, Smith D, Ho A. The effect of loupes on neck pain and disability among dental hygienists. Work 2016;53(4):755-62.

[19] Branson BG, Black MA, Beck MS. Changes in posture: A case study of a dental hygienist's use of magnification loupes. Work 2010;35:467-76.
[20] Szymanska J. Disorders of the musculoskeletal system among dentists from the aspect of ergonomics and prophylaxis. Ann Agric Environ Med 2002;9:169-73.

[21] Anton D, Rosecrance J, Merlino L, Cook T. Prevalence of musculoskeletal symptoms and carpal tunnel syndrome among dental hygienists. Am J Ind Med 2002;42:248-57.

[22] Finsen L, Christensen H, Bakke M. Musculoskeletal disorders among dentists and variation in dental work. Appl Ergon 1998;29:119-25.

[23] Leggat PA, Smith DR. Musculoskeletal disorders selfreported by dentists in Queensland, Australia. Aust Dent J 2006;51:324-27.

[24] AlWazzan KA, Almas K, ElShethri SE, AlQuahtani MQ. Back and neck problems among dentists and dental auxiliaries. J Contemp Dent Pract 2001;2:1-10.

[25] Lindorfs P, von Theile U, Lundberg U. Work characteristics and upper extremity disorders in female dental health workers. J Occup Health 2006;48:192-7.

[26] Sartorio F, Vercelli S, Ferriero G, D'Angelo F, Migliario M, Franchignoni M. Work-related musculoskeletal diseases in dental professionals.1. Prevalence and risk factors. G Ital Med Lav Ergon 2005;27:165-9.

[27] Hornqwist Bylunda S, Christina Ahlgren. Experiences and consequences for women with hand-arm vibration injuries. Work 2010;35:431-9.

[28] Newton JT, Mistry K, Patel A, Patel P, Perkins M, Saeed $\mathrm{K}$, et al. Stress in Dental Specialists: A Comparison of Six Clinical Dental Specialties. Prim Dent Care 2002;9(3):1005 .

[29] Callaghan J, McGill S. Low back joint loading and kinematics during standing and unsupported sitting. Ergonomics 2001;44(3):280-94.

[30] Pejčić N, Djurić-Jovicić M, Miljković N, Popović DD, Petrović V. Posture in dentists: Sitting vs. standing positions during dentistry work - An EMG study. Srp Arh Celok Lek 2016;144(3-4):181-7.

[31] Beach JC, DeBaise CB. Assessment of ergonomic education in dental hygiene curricula. J Dent Educ 1998;62(6):421-5.

[32] Gilmour J, Stewardson DA, Shugars DA, Burke FJ. An assessment of career satisfaction among a group of general dental practitioners in Staffordshire. Br Dent $\mathrm{J}$ 2005;198(11):701-4.

[33] Goebring C, Gallacchi MB, Kunzi B, Bovier P. Psychosocial and professional characteristics of burnout in Swiss primary care practitioners: A cross-sectional survey. Swiss Med Wkly 2005;135:101-8.

[34] Baran ORB. Myers B. Type Indicator, burnout, and satisfaction in Illinois dentists. Gen Dent 2005;53(3):228-34.

[35] Malmgren-Olsson EB, Armelius BE. Physical and psychological health and social relations in patients with prolonged musculoskeletal disorders. Scand J Caring Sci 2001;15: 181-9.

[36] Moore R, Brodsgaard I. Dentists' perceived stress and its relation to perceptions about the anxious patients. Community Dent Oral Epidemiol 2001;29:73-80.

[37] Hamann CP, Depaola LG, Rodgers PA. Occupationalrelated allergies in dentistry. J Am Dent Assoc 2005;136:500-10. 


\section{Appendix 1}

Respected colleagues,

\section{QUESTIONNAIRE - ERGONOMICS IN DENTISTRY}

During daily work we are fully committed to our patients, in order to offer them professional and quality service and support.

At the same time, we often neglect ourselves, our body position, attitude, habits during the work. It all could have implications on our health. Clinical intraoral examination, as well as the most frequent dental procedures has always required certain unnatural body postures.

Dentists are at high risk for developing MSDs because of frequently awkward body postures, overextended positions while performing dental procedures, repetitive and highly forceful motions, prolonged static positions and unsupported sitting as well as the extended workdays.

The pain in certain parts of the body can result in cumulative micro trauma which affected dentists as consequences of frequent, repeated and prolonged unhealthy body positions while performing different dental procedures.

Recently many researchers have suggested that dentists often suffer from different musculoskeletal diseases as a consequence of non-ergonomic workplace conditions. The term "ergonomics" increasingly became very popular within dental profession. It is a multi-and interdisciplinary discipline that studies workers and their relationship to their occupational environment.

Since we do not have adequate information about the health of dentists, as well as the factors that influence on process and quality of work, please fill out the questionnaire that will not take more than 15 minutes, and obtained information will be considerable for assessment situation in this area.

In hope that you will honestly fill out the questionnaire

We are very grateful 


\begin{tabular}{|c|c|c|c|c|}
\hline \multicolumn{5}{|c|}{$\begin{array}{l}\text { QUESTIONNARE } \\
\end{array}$} \\
\hline 1. Year of Birth & & & & \\
\hline 2. Gender & \multicolumn{2}{|c|}{ Male } & \multicolumn{2}{|r|}{ Female } \\
\hline \multicolumn{5}{|l|}{ 3. Years of study dentistry } \\
\hline \multicolumn{5}{|l|}{$\begin{array}{l}\text { 4. Years of working } \\
\text { experience in dentistry }\end{array}$} \\
\hline \multicolumn{5}{|l|}{ 5. Place of work } \\
\hline 6. Do you have children? & \multicolumn{2}{|c|}{ Yes } & \multicolumn{2}{|r|}{ No } \\
\hline \multicolumn{5}{|l|}{$\begin{array}{cc}\text { 7. } & \text { Height: } \\
& {[\mathrm{cm}]}\end{array}$} \\
\hline \multicolumn{5}{|l|}{$\begin{array}{ll}\text { 8. } & \text { Weight: } \\
& {[\mathrm{kg}]} \\
\end{array}$} \\
\hline $\begin{array}{l}\text { 9. Do you have post } \\
\text { graduate diploma? }\end{array}$ & \multicolumn{2}{|c|}{ Yes } & & No \\
\hline \multicolumn{5}{|l|}{$\begin{array}{l}\text { 10. If you are a consultant, } \\
\text { from which field? }\end{array}$} \\
\hline $\begin{array}{l}\text { 11. Are you satisfied with } \\
\text { your occupation? }\end{array}$ & \multicolumn{2}{|c|}{ Yes } & \multicolumn{2}{|r|}{ No } \\
\hline $\begin{array}{l}\text { 12. In what kind of } \\
\text { institution do you work? }\end{array}$ & Public & & Private & Both \\
\hline 13. Are you & \multicolumn{2}{|c|}{ left-handed } & & right-handed \\
\hline $\begin{array}{l}\text { 14. If you are left-handed, } \\
\text { which hand do you use } \\
\text { during work? }\end{array}$ & \multicolumn{2}{|c|}{ left hand } & & right hand \\
\hline $\begin{array}{l}\text { 15. Preferred working } \\
\text { position }\end{array}$ & sitting & standing & & $\begin{array}{l}\text { alternating sitting and standing } \\
\text { positions }\end{array}$ \\
\hline \multirow{4}{*}{$\begin{array}{l}\text { 16. Do you have } \\
\text { therapeutic chair with } \\
\text { support in: }\end{array}$} & \multicolumn{4}{|c|}{ a) lumbar region } \\
\hline & \multicolumn{4}{|c|}{ b) thoracic region } \\
\hline & \multicolumn{4}{|c|}{ c) both, lumbar and thoracic region } \\
\hline & \multicolumn{4}{|c|}{ d) do not provide any support } \\
\hline $\begin{array}{l}\text { 17. Do you use chair with } \\
\text { adequate therapeutic } \\
\text { armrest? }\end{array}$ & \multicolumn{2}{|c|}{ Yes } & & No \\
\hline \multicolumn{5}{|l|}{$\begin{array}{l}\text { 18. Length of working time } \\
\text { during the day[h] }\end{array}$} \\
\hline $\begin{array}{l}\text { 19. Number of working } \\
\text { days during the week: }\end{array}$ & & & & \\
\hline
\end{tabular}




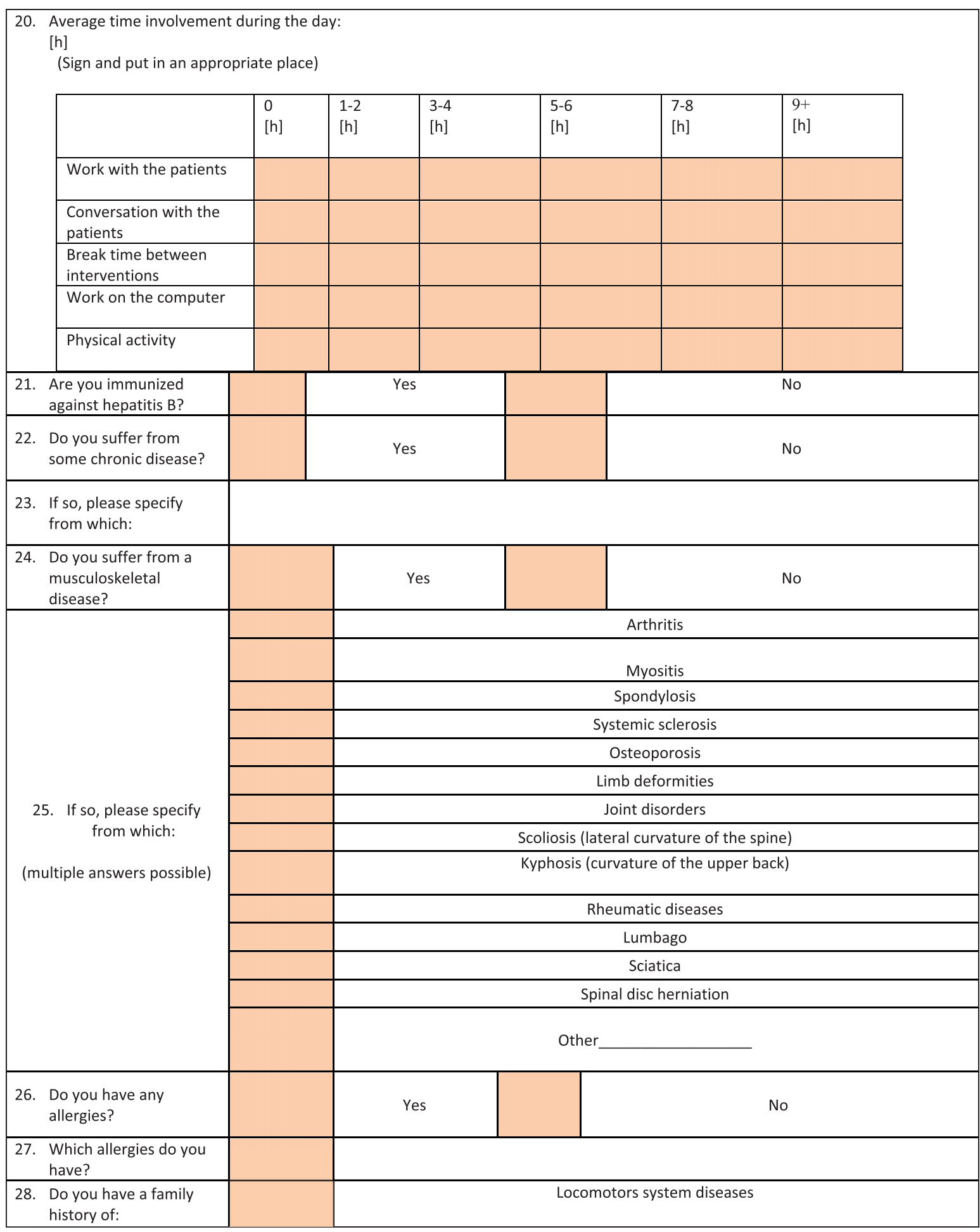




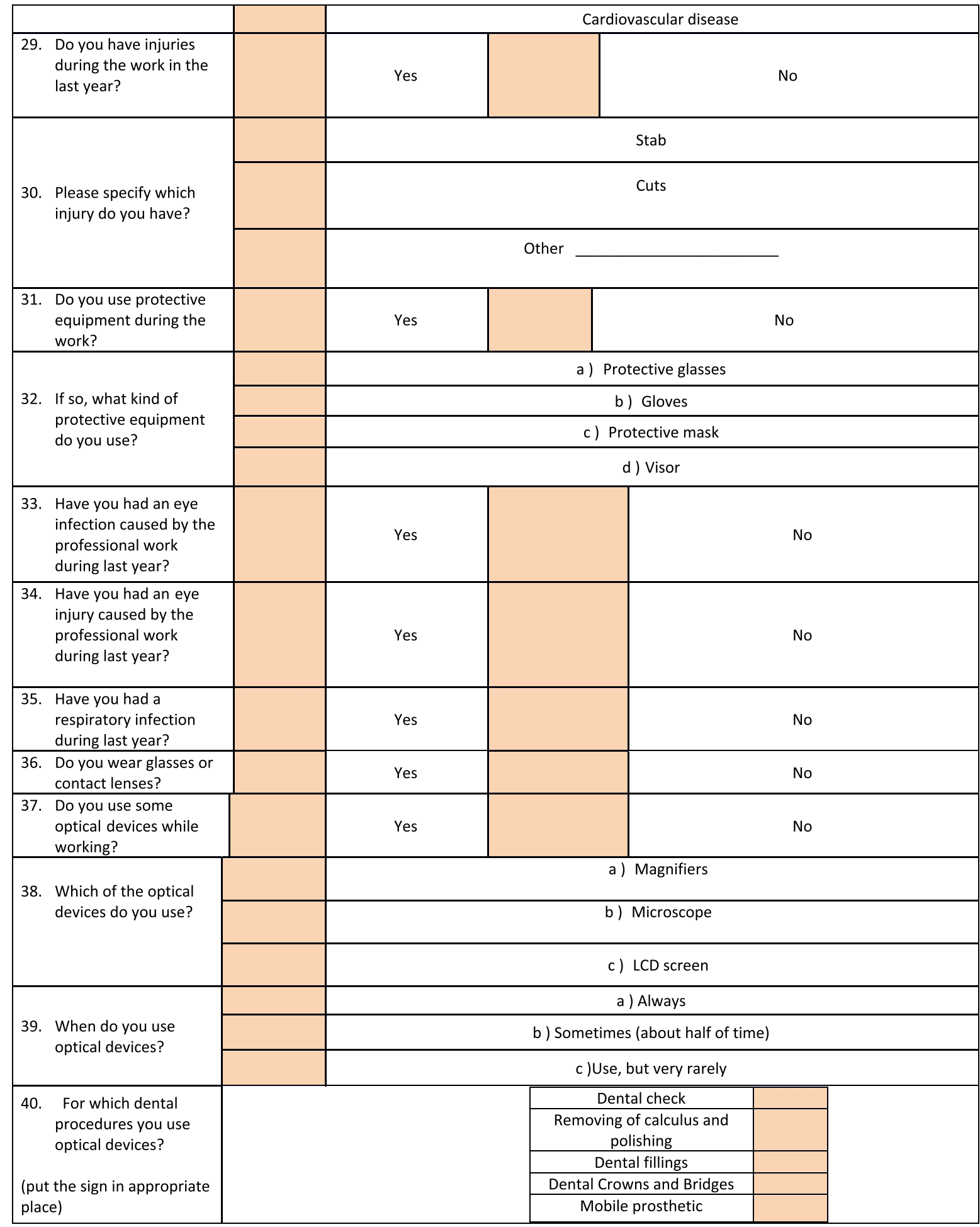




\begin{tabular}{|c|c|c|c|c|}
\hline & & & replacements & \\
\hline & & & Orthodontics & \\
\hline & & & Endodontics & \\
\hline & & & Periodontal surgery & \\
\hline & & & Tooth extraction & \\
\hline & & & Working with children & \\
\hline \multicolumn{2}{|c|}{$\begin{array}{l}\text { 41. Does it often happen } \\
\text { that you working in } \\
\text { the same position } \\
\text { longer than } 40 \mathrm{~min} \text { ? }\end{array}$} & Yes & & No \\
\hline & $\begin{array}{l}\text { Are you trying to work } \\
\text { in a proper body } \\
\text { position? }\end{array}$ & Yes & & No \\
\hline & $\begin{array}{l}\text { Do you feel } \\
\text { discomfort while } \\
\text { working in a certain } \\
\text { body positions? }\end{array}$ & Yes & & No \\
\hline & $\begin{array}{l}\text { Do you manage to } \\
\text { work without } \\
\text { stretching, twisting } \\
\text { or tilting movement? }\end{array}$ & Yes & & No \\
\hline & $\begin{array}{l}\text { The average number } \\
\text { of patients during the } \\
\text { working week: }\end{array}$ & & & \\
\hline & $\begin{array}{l}\text { Do you work with } \\
\text { dental assistant? }\end{array}$ & Yes & & No \\
\hline & $\begin{array}{l}\text { Are you taking any } \\
\text { recreational physical } \\
\text { activity? }\end{array}$ & Yes & & No \\
\hline \multirow{4}{*}{\multicolumn{2}{|c|}{ 48. If so, how often? }} & \multicolumn{3}{|c|}{ a) everyday } \\
\hline & & \multicolumn{3}{|c|}{ b) 3 times per week } \\
\hline & & \multicolumn{3}{|c|}{ c) once a week } \\
\hline & & \multicolumn{3}{|c|}{ d) not taking up exercise } \\
\hline & $\begin{array}{l}\text { Are you taking a } \\
\text { massage treatments? }\end{array}$ & Yes & & No \\
\hline \multirow{4}{*}{\multicolumn{2}{|c|}{ 50. If so, how often? }} & \multicolumn{3}{|c|}{ a) 3 times per week } \\
\hline & & \multicolumn{3}{|c|}{ b) once a week } \\
\hline & & \multicolumn{3}{|c|}{ c) once a month } \\
\hline & & \multicolumn{3}{|c|}{ d) occasionally } \\
\hline & $\begin{array}{l}\text { Do you feel pain in } \\
\text { some parts of the } \\
\text { body, during the } \\
\text { work? }\end{array}$ & Yes & & No \\
\hline \multirow{2}{*}{\multicolumn{2}{|c|}{$\begin{array}{l}\text { 52. If so, in which part of } \\
\text { the body you feel } \\
\text { pain? }\end{array}$}} & \multicolumn{3}{|c|}{ Neck } \\
\hline & & \multicolumn{3}{|c|}{ Lumbar region } \\
\hline
\end{tabular}




\begin{tabular}{|c|c|c|c|}
\hline \multirow[t]{10}{*}{ (multiple answers possible) } & \multicolumn{3}{|c|}{ Thoracic region } \\
\hline & \multicolumn{3}{|c|}{ Left shoulder } \\
\hline & \multicolumn{3}{|c|}{ Right shoulder } \\
\hline & \multicolumn{3}{|c|}{ Both shoulders } \\
\hline & \multicolumn{3}{|c|}{ Hands } \\
\hline & \multicolumn{3}{|c|}{ Wrist } \\
\hline & \multicolumn{3}{|c|}{ Hand fingers } \\
\hline & \multicolumn{3}{|c|}{ Knees } \\
\hline & \multicolumn{3}{|c|}{ Feet } \\
\hline & \multicolumn{3}{|c|}{ Other } \\
\hline $\begin{array}{l}\text { 53. If you have pain in the } \\
\text { hand, where it is } \\
\text { localized: }\end{array}$ & $\begin{array}{l}\text { In the area of the } \\
\text { palm }\end{array}$ & In the upper part of hand & In both areas \\
\hline $\begin{array}{l}\text { 54. Do you have varicose } \\
\text { veins? }\end{array}$ & Yes & & No \\
\hline $\begin{array}{l}\text { 55. Do you often have a } \\
\text { headache? }\end{array}$ & Yes & & No \\
\hline $\begin{array}{l}\text { 56. Do you feel a loss of } \\
\text { coordination and } \\
\text { normal sensation in } \\
\text { the hands? }\end{array}$ & Yes & & No \\
\hline $\begin{array}{l}\text { 57. Do you fell stiffness } \\
\text { and numbness in the } \\
\text { area of the fingers, } \\
\text { hands, arms, forearms } \\
\text { and shoulders? }\end{array}$ & Yes & & No \\
\hline $\begin{array}{l}\text { 58. Do you feel increased } \\
\text { fatigue in the area of } \\
\text { the fingers, hands, } \\
\text { arms, forearms and } \\
\text { shoulders? }\end{array}$ & Yes & & No \\
\hline $\begin{array}{l}\text { 59. Do you have problem } \\
\text { with sleeping? }\end{array}$ & Yes & & No \\
\hline \multicolumn{4}{|l|}{$\begin{array}{l}\text { 60. After how many years } \\
\text { of practice, have you } \\
\text { felt pain? }\end{array}$} \\
\hline 61. Is the pain: & \multicolumn{2}{|c|}{ Chronic } & Acute \\
\hline \multicolumn{4}{|l|}{$\begin{array}{l}\text { 62. If the pain is acute, } \\
\text { which is the duration } \\
\text { of painful episodes? } \\
{[\mathrm{h}]}\end{array}$} \\
\hline $\begin{array}{l}\text { 63. Does the pain } \\
\text { interfere with your }\end{array}$ & Yes & & No \\
\hline
\end{tabular}




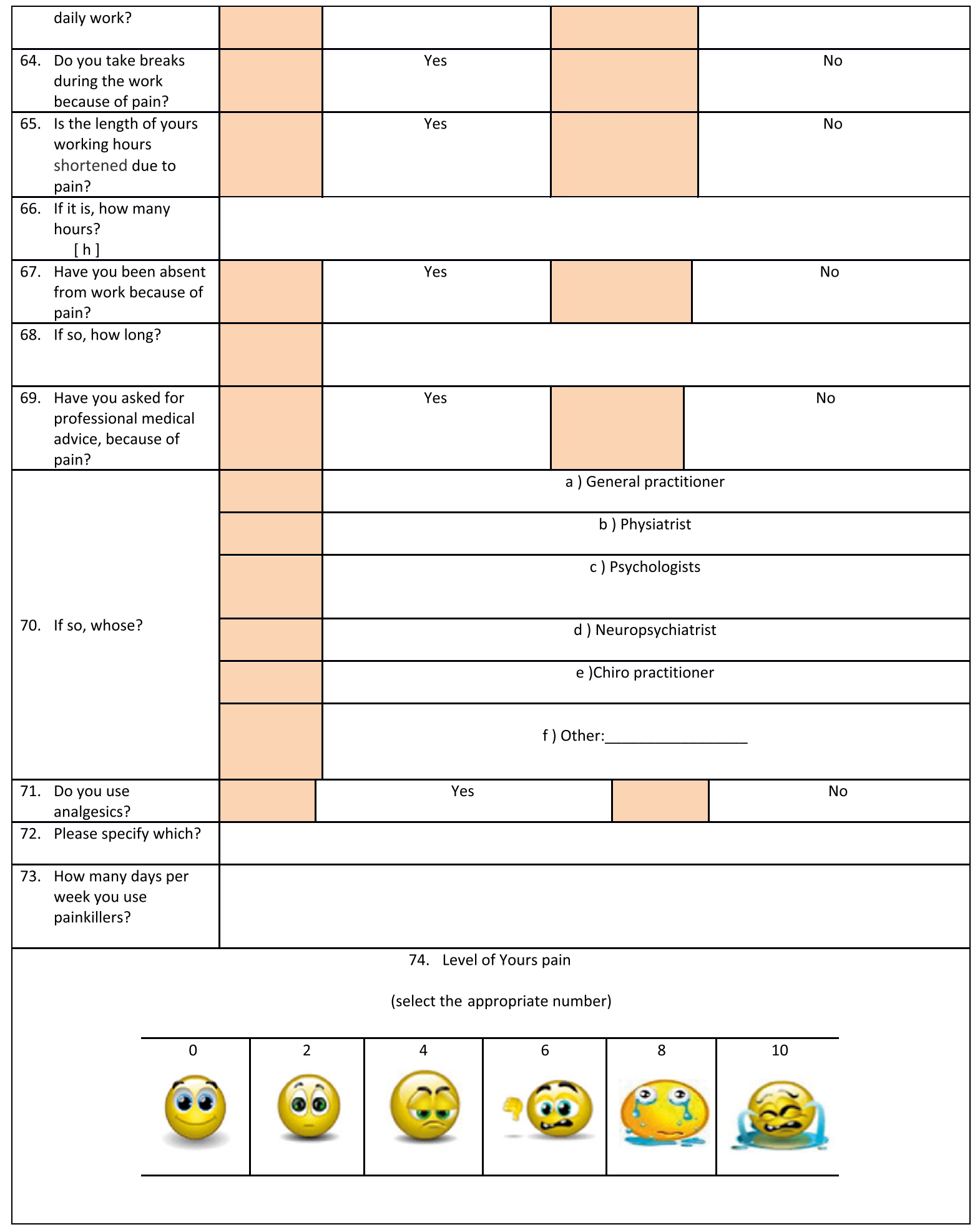


75. What is yours subjective feeling of physical effort during the following dental treatment?

( select the appropriate number )

0 - Completely effortless

10 - Maximum effort

\begin{tabular}{|c|c|}
\hline Dental procedures & 0246810 \\
\hline $\begin{array}{c}\text { Dental check } \\
\text { Removing of calculus and } \\
\text { polishing }\end{array}$ & 0246810 \\
\hline Dental fillings & 0246810 \\
\hline $\begin{array}{c}\text { Dental Crowns and } \\
\text { Bridges }\end{array}$ & 024681010 \\
\hline $\begin{array}{c}\text { Mobile prosthetic } \\
\text { replacements }\end{array}$ & 0246810 \\
\hline Orthodontics & 0246810 \\
\hline Endodontics & 0246810 \\
\hline Periodontal surgery & 0246810 \\
\hline Tooth extraction & 0246810 \\
\hline Working with children & 0246810 \\
\hline
\end{tabular}

76. What is yours subjective feeling of mentally effort during the following dental treatment?

( select the appropriate number)

0 - Completely effortless

10 - Maximum effort

\begin{tabular}{|c|c|}
\hline Dental procedures & \\
\hline Dental check & $\begin{array}{llllll}0 & 2 & 4 & 6 & 8 & 10 \\
\end{array}$ \\
\hline $\begin{array}{c}\text { Removing of calculus and } \\
\text { polishing }\end{array}$ & 0246810 \\
\hline Dental fillings & 0224468810 \\
\hline $\begin{array}{c}\text { Dental Crowns and } \\
\text { Bridges } \\
\end{array}$ & 024681010 \\
\hline $\begin{array}{l}\text { Mobile prosthetic } \\
\text { replacements }\end{array}$ & 0246810 \\
\hline Orthodontics & 0246810 \\
\hline Endodontics & 02466810 \\
\hline Periodontal surgery & 02246810 \\
\hline Tooth extraction & 02446810 \\
\hline Working with children & $\begin{array}{llllll}0 & 2 & 4 & 6 & 8 & 10 \\
\end{array}$ \\
\hline
\end{tabular}


77. How often do you perform following procedures?

( put the sign in appropriate place)

\begin{tabular}{|c|l|l|l|l|}
\hline Dental procedures & The most frequent & Often & Rarely & Never \\
\hline Dental check & & & & \\
\hline $\begin{array}{c}\text { Removing of calculus } \\
\text { and polishing }\end{array}$ & & & & \\
\hline Dental fillings & & & & \\
\hline $\begin{array}{c}\text { Dental Crowns and } \\
\text { Bridges }\end{array}$ & & & & \\
\hline $\begin{array}{c}\text { Mobile prosthetic } \\
\text { replacements }\end{array}$ & & & & \\
\hline Orthodontics & & & & \\
\hline Endodontics & & & & \\
\hline Periodontal surgery & & & & \\
\hline Tooth extraction & & & & \\
\hline Working with children & & & & \\
\hline
\end{tabular}

78. After which dental procedures you most often feel fatigue and pain? (put the sign in appropriate place)

\begin{tabular}{|c|c|}
\hline Dental check & \\
\hline $\begin{array}{c}\text { Removing of calculus and } \\
\text { polishing }\end{array}$ & \\
\hline Dental fillings & \\
\hline Dental Crowns and Bridges & \\
\hline $\begin{array}{c}\text { Mobile prosthetic } \\
\text { replacements }\end{array}$ & \\
\hline Orthodontics & \\
\hline Endodontics & \\
\hline Periodontal surgery & \\
\hline Tooth extraction & \\
\hline Working with children & \\
\hline
\end{tabular}

